\title{
A Loop-Mediated Isothermal Amplification (LAMP) Assay for Rapid and Specific Detection of Airborne Inoculum of Uromyces betae (Sugar Beet Rust)
}

Agata M. Kaczmarek, ${ }^{\dagger}$ School of Biosciences, University of Nottingham, Sutton Bonington Campus, Loughborough, Leicestershire, U.K.; and Rothamsted Research, Harpenden, Hertfordshire, U.K.; Kevin M. King and Jonathan S. West, Rothamsted Research, Harpenden, Hertfordshire, U.K.; Mark Stevens, British Beet Research Organisation (BBRO), Innovation Centre, Norwich Research Park, Norwich, U.K.; and Debbie Sparkes and Matthew J. Dickinson, School of Biosciences, University of Nottingham, Sutton Bonington Campus, Loughborough, Leicestershire, U.K.

\begin{abstract}
Sugar beet rust disease (causal agent Uromyces betae) represents a serious threat to worldwide sugar beet (Beta vulgaris) crops, causing yield losses of up to $10 \%$ in the United Kingdom. Currently, the disease is managed mainly by application of fungicides after rust disease symptoms appear. Development of a future forecasting system, incorporating data on environmental factors and $U$. betae inoculum levels, would enable better disease control by more targeted application of fungicides. In this study, we developed a first molecular diagnostic, targeted to cytochrome $b$ DNA sequences and based on loopmediated isothermal amplification (LAMP) technology, for rapid ( $<30 \mathrm{~min}$ ) and specific detection of $U$. betae. The new assay only detected $U$. betae strains (collected from across eastern England, the

main sugar beet growing region in the United Kingdom) and Denmark; it did not detect other closely related pathogens (e.g., Puccinia sp., U. fabae) or others that are commonly found on sugar beet (Cercospora beticola, Erysiphe betae, Ramularia beticola). The assay could consistently detect down to small amounts of $U$. betae DNA $(10 \mathrm{pg})$. Application of the new LAMP diagnostic to air spore tape samples collected between mid-June and mid-September from a single U.K. sugar beet field site revealed differences in temporal patterns of pathogen inoculum between the 2015 and 2016 seasons. The described LAMP assay could now be used as a component of a future automated inoculum-based forecasting system, enabling more targeted control of sugar beet rust disease.
\end{abstract}

Sugar beet rust is a disease of sugar beet (Beta vulgaris) crops caused by the biotrophic basidiomycete fungus Uromyces betae. Typical foliar disease symptoms include circular orange-brown pustules that can occur on both upper and lower leaf surfaces and are typically around 1 to $2 \mathrm{~mm}$ in diameter (Draycott 2008). Severe outbreaks of sugar beet rust can cause reduced green leaf area available for photosynthesis, and reported yield reductions can be $\approx 1 \%$ root sugar content and $\approx 15 \%$ of total root weight (OEPP/EPPO 1994). The disease was first described in Canada in 1935 (Newton and Peturson 1943) and subsequently in Europe in 1988 (O'Sullivan 1997). In the United Kingdom, mild weather conditions throughout the year (i.e., cooler summers, warmer winters) are conducive for disease development (Draycott 2008). Indeed, in 2015, sugar beet rust was the most important disease of sugar beet crops in Britain (Mark Stevens, British Beet Research Organisation [BBRO], unpublished data).

Effective control of sugar beet rust is achieved by integrated use of resistant cultivars, cultural practices (e.g., crop rotation), and mainly use of fungicides including those with different modes of action (e.g., Escolta [cyproconazole + trifloxystrobin]). Previous studies have demonstrated that chemical control can increase sugar beet crop yields and improve quality (O'Sullivan 1997; Soerensen and Marcussen 1996). At present, decisions on fungicide use are based largely on visual rust disease symptoms, and they are applied when the first symptoms are spotted (Draycott 2008; OEPP/EPPO 1994).

${ }^{\dagger}$ Corresponding author: Agata M. Kaczmarek;

E-mail: agata.kaczmarek@nottingham.ac.uk

Funding: This study was funded by Innovate UK (SporeID/102104) and the University of Nottingham. Rothamsted Research receives strategic funding from the Biotechnology and Biological Sciences Research Council's Industrial Strategy Challenge Fund, Smart Crop Protection strategic programme (BBS/OS/CP/000001)

Accepted for publication 27 August 2018.

(c) 2019 The American Phytopathological Society
Molecular diagnostics already exist and enable rapid, sensitive, and specific detection for a number of different phytopathogens, and when used alongside air spore trap samplers they can be used to detect airborne pathogen inoculum (Williams et al. 2001). However, at present no molecular diagnostic is yet available that specifically targets $U$. betae (partly owing to the biotrophic and hence unculturable in vitro nature of the fungus), with fungal species confirmation thus requiring relatively time-consuming and expensive morphometric analyses and/or DNA sequencing. Development of a first molecular diagnostic for direct detection of $U$. betae could potentially allow early detection of airborne inoculum (splash-dispersed urediospores that while airborne are further spread by wind) and could also allow detection even when disease is asymptomatic.

First described by Notomi et al. (2000) loop-mediated isothermal amplification (LAMP) assays have been developed for fast, sensitive, and specific detection of a diverse range of plant pathogen species (Bekele et al. 2011; Duan et al. 2014; Kogovšek et al. 2015; Tomlinson et al. 2010, 2013a, b). LAMP requires at least four specific primers: two outer primers (by convention FIP and BIP) and two inner primers (F3 and $\mathrm{B} 3$ ) in combination with DNA polymerase enzyme with strand displacement activity. Furthermore, incorporation of additional loop primers can greatly increase the speed and sensitivity of the assay (Nagamine et al. 2002). LAMP technology also has several other potentially advantageous features including the requirement for only a single reaction temperature, quantification of pathogen DNA/inoculum (Aoi et al. 2006), and potential lyophilization of reaction reagents.

Development of a first $U$. betae LAMP assay, capable of early detection of airborne pathogen inoculum, could lead to potential incorporation as a component of a future inoculum-based forecasting system. Such a tool could be used to guide disease management decisions by end user growers. Therefore, the specific aims of this study were (i) to develop and validate a rapid and specific LAMP assay for $U$. betae and (ii) to demonstrate its applied use for inoculum detection in air environmental samples.

\section{Materials and Methods}

Spore material and DNA extraction. Field strains of $U$. betae were collected from symptomatic leaves from five different locations 
throughout England representing the main sugar beet growing regions in the United Kingdom: Essex, North Lincolnshire, Nottingham, South Lincolnshire, and Suffolk) (from commercial sugar beet field trials involved in the SporeID Technology Strategy Board project led by BBRO). U. betae pustules were then scraped from the leaf surface with a sterile needle under a stereomicroscope (Olympus $\mathrm{BH}-2$ ). Additionally, some leaves were air dried and spores tapped out from the leaves and stored at $-20^{\circ} \mathrm{C}$ until needed. Genomic DNA was subsequently extracted from frozen $U$. betae spores using a Qiagen DNeasy Plant Mini Kit (Qiagen, U.K.) and quantified using a nanodrop photospectrometer. Samples were diluted to the required concentration using polymerase chain reaction (PCR) grade water.

Sequencing and LAMP assay primer design. Initial attempts to design a $U$. betae-specific LAMP assay based on internal transcribed spacer (ITS) region sequences were unsuccessful owing to insufficient variation between the target and other closely related species (data not shown). Thus, the alternative cytochrome $b$ gene region

Table 1. List of the primers targeted to cytochrome $b$ DNA sequences used in this study ${ }^{\mathrm{a}}$

\begin{tabular}{ll}
\hline Technique/primer name & Sequence \\
\hline Conventional PCR & \\
PuccytB2F & TCTGAGTAATAGGTGACGGT \\
PuccytB2R & AAAGGAATGTGAGTTAGCGT \\
LAMP & \\
RCytBF3 & GTACACGTCTAACTCAAGTTCT \\
RCytBB3 & TCATCAGTGTCGCCCTAA \\
RCytBFIP (F1+F2) & GCAAGATACCATATGC \\
& GGTCGTTGTGAAGTCAAGT \\
RCytBBIP (B1+B2) & GTACAATCA \\
& ATGCCGCTTCTATACATTAGGCTAT \\
RCytBLoopF & GTAGATCGAACATCGATTCAGC \\
RCytBLoopB & AGTCCTTATAGTCCGAACAGAT \\
\hline
\end{tabular}

${ }^{a} \mathrm{PCR}=$ polymerase chain reaction, and LAMP $=$ loop-mediated isothermal amplification.

Table 2. Fungal strains screened against the developed Uromyces betae LAMP assay ${ }^{\mathrm{a}}$

\begin{tabular}{|c|c|c|}
\hline $\begin{array}{l}\text { Fungal species } \\
\text { (1 ng of DNA per reaction) }\end{array}$ & $\begin{array}{l}\text { Origin (all United } \\
\text { Kingdom unless } \\
\text { specified) }\end{array}$ & $\begin{array}{l}\text { LAMP } \\
\text { result }\end{array}$ \\
\hline $\begin{array}{l}\text { Puccinia triticina (wheat } \\
\text { leaf rust, both yellow } \\
\text { and brown) }\end{array}$ & $\begin{array}{l}\text { University of Nottingham } \\
\text { (UoN) Rothamsted } \\
\text { Research Institute (RRes) }\end{array}$ & - \\
\hline \multirow[t]{9}{*}{ U. betae (sugar beet rust) } & UoN, RRes & \\
\hline & $\begin{array}{l}\text { Leicestershire (Sutton } \\
\text { Bonington), }\end{array}$ & + \\
\hline & $\begin{array}{l}\text { South Lincolnshire } \\
\text { (Barkston) }\end{array}$ & + \\
\hline & Suffolk (Garboldisham) & + \\
\hline & Oxfordshire (Oxford) & + \\
\hline & Nottingham (Bracebridge) & + \\
\hline & $\begin{array}{l}\text { Aarhus University and NBR } \\
\text { (Denmark) }\end{array}$ & \\
\hline & Flakkebjerg & + \\
\hline & Glasshouse isolates & + \\
\hline $\begin{array}{l}\text { Erysiphe betae (sugar beet } \\
\text { powdery mildew) }\end{array}$ & UoN & - \\
\hline $\begin{array}{l}\text { Botrytis cinerea (Botrytis } \\
\text { storage rot) }\end{array}$ & RRes & - \\
\hline Erysiphe sp. (tomato mildew) & RRes & - \\
\hline Uromyces viciae-fabae (bean rust) & RRes & - \\
\hline Alternaria alternata (leaf spot) & RRes & - \\
\hline $\begin{array}{l}\text { Cercospora beticola (Cercospora } \\
\text { leaf spot of sugar beet) }\end{array}$ & UoN & - \\
\hline $\begin{array}{l}\text { Ramularia beticola (Ramularia } \\
\text { of sugar beet) }\end{array}$ & UoN & - \\
\hline
\end{tabular}

${ }^{\mathrm{a}}$ LAMP $=$ loop-mediated isothermal amplification. was instead selected, because of its high gene copy number, and because variation in this gene had previously proved useful for development of molecular diagnostics for specific detection and phylogeny of pathogenic fungi (Biswas et al. 2001; Grasso et al. 2006; Wang et al. 1998).

Given that no $U$. betae cytochrome $b$ sequences were yet available in GenBank, new primers were designed (PuccytB2F/R; Table 1) using PRIMER BLAST (Ye et al. 2012) to target an approximately 584-bp region of the gene in this species (these conserved primers were designed based on aligned sequences of closely related Puccinia and Uromyces species; DQ209276, AF511082, and AF426199). For the development of LAMP assays, cytochrome $b$ sequence data were obtained for five representative $U$. betae field strains obtained from the main sugar beet growing regions of the United Kingdom (Leicestershire, South Lincolnshire, Suffolk, Oxford, and Nottinghamshire) (Table 2). PCRs $(25 \mu \mathrm{l})$ contained $12.5 \mu \mathrm{l}$ of Mango Mastermix ( $1 \times$ final concentrate; Bioline), $9.5 \mu \mathrm{l}$ of PCR grade water (HyClone), $1 \mu$ l of each primer PuccytB2F and PuccytB2R (with a final concentration of $0.4 \mu \mathrm{M}$ of each of them), and $1 \mu \mathrm{l}$ of crude DNA templates (between 20 and $30 \mathrm{ng}$ ). PCR conditions were as follows: $94^{\circ} \mathrm{C}$ for $2 \mathrm{~min}$; followed by 30 cycles of $94^{\circ} \mathrm{C}$ for $1 \mathrm{~min}, 50^{\circ} \mathrm{C}$ for $1 \mathrm{~min}$, and $72^{\circ} \mathrm{C}$ for $2 \mathrm{~min}$; and finally $72^{\circ} \mathrm{C}$ for $10 \mathrm{~min}$. PCR products were visualized under ultraviolet light on an agarose gel incorporated with ethidium bromide. Amplicons were purified using a Qiagen MinElute PCR purification kit and sent for sequencing (using primer PuccytB2F) to MWG Eurofins Genomics. Newly obtained cytochrome $b$ sequences were identical for all five of the $U$. betae strains (representative sequence deposited in GenBank under accession MF426925) and were subsequently aligned with closely related Puccinia and Uromyces species (GenBank accession nos. DQ209276,
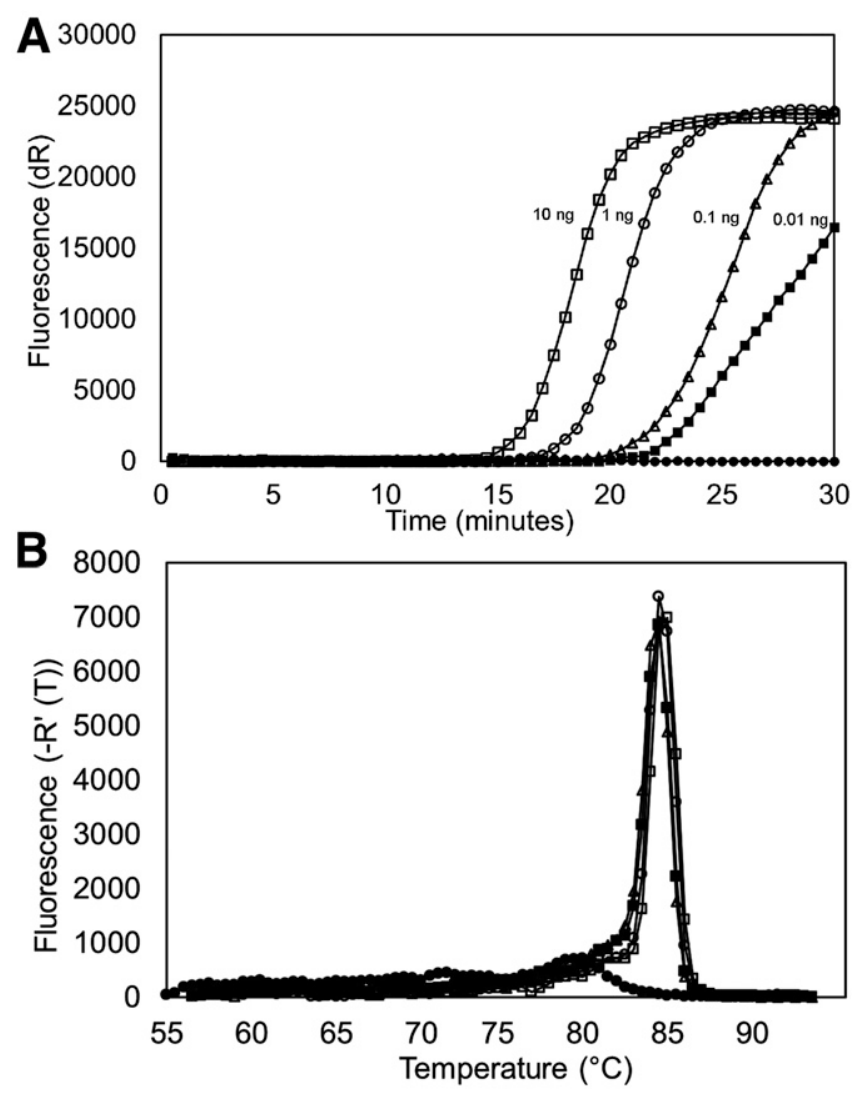

Fig. 1. Representative results obtained using the new Uromyces betae LAMP assay developed in this study. A, Amplification (on log scale) of a dilution series of $U$. betae DNA (10 to $0.01 \mathrm{ng}$ ) and a no template control ( $x$ axis denotes time in minutes). $B$, The corresponding dissociation plots for the four positive samples (peaks at 84 to $85^{\circ} \mathrm{C}$ ), and the single no template control (no clear peak evident). Fluorescence values $(R)$ are in arbitrary units. 
AF511082, and AF426199) (van der Merwe et al. 2007). Finally, LAMP primers targeted specifically to $U$. betae were designed using LAMP Designer Software (OptiGene, U.K.) (Table 1).

Validation of the $U$. betae LAMP assay. The analytical specificity of the newly designed LAMP assay to the cytochrome $b$ DNA sequence of $U$. betae was assessed by screening against a panel of other fungal species that were either closely related or often found on sugar beet plants (Table 2). LAMP reactions were done in $24-\mu 1$ volumes, each containing: 12. $8 \mu \mathrm{l}$ of isothermal mastermix (ISO001, OptiGene), $2.5 \mu \mathrm{l}$ of primer mix (at final reaction concentrations of FIP/BIP, $1.3 \mu \mathrm{M}$; LoopB/F, $0.42 \mu \mathrm{M}$; and B3/F3, $0.16 \mu \mathrm{M}$ ), $4.7 \mu \mathrm{l}$ of PCR grade water, and $4 \mu \mathrm{l}$ of DNA template (1 ng total). LAMP testing was done using a Stratagene Mx3000 Pro real-time PCR machine, with the optimal isothermal temperature being $61^{\circ} \mathrm{C}$ for $30 \mathrm{~min}$ (FAM fluorescence measured every $30 \mathrm{~s}$ ); this was followed by melting curve analysis at $95^{\circ} \mathrm{C}$ for $1 \mathrm{~min}, 55^{\circ} \mathrm{C}$ for $30 \mathrm{~s}$, and $95^{\circ} \mathrm{C}$ for $30 \mathrm{~s}$. Data were analyzed on the log scale with the cycle threshold $(\mathrm{Ct})$ adjusted manually to the exponential phase of the amplification curves. Each sample was run with three technical replicates and was considered positive only if all three gave a $\mathrm{Ct}$ value of $<60$ (i.e., within $30 \mathrm{~min}$ ).

The analytical sensitivity of the developed assay was initially evaluated by screening against differing amounts of total $U$. betae genomic DNA: $10 \mathrm{ng}, 1 \mathrm{ng}, 100 \mathrm{pg}, 10 \mathrm{pg}$, and $1 \mathrm{pg}$. Subsequently, sensitivity was investigated by using the known number of spores measured by a hemocytometer suspended in sterile distilled water. The spore suspension was applied as $10-\mu l$ droplets (containing known total amounts of spores as follows: 10,000, 1,000, 100, 10, and 1 spores) and air dried in a sterile laminar flow hood for $1 \mathrm{~h}$ onto Melinex tape segments. DNA was extracted using a MASTERPURE Yeast DNA Purification kit (Epicentre, U.S.A.) according to the manufacturer's instructions.

Each LAMP reaction contained the DNA dilution equivalent to $100,10,1,0.1$, or 0.01 spores. Three DNA extract replicates from each of the different amounts of $U$. betae spores were tested, with three technical replicates for each sample tested with LAMP. Reaction components and conditions were as listed above.
Application of the $U$. betae LAMP assay to air spore tape samples. Burkard spore traps were positioned within a sugar beet field located in Suffolk $\left(52^{\circ} 19^{\prime} 17.1^{\prime \prime} \mathrm{N}, 0^{\circ} 48^{\prime}\right.$ $36.7^{\prime \prime} \mathrm{E}$ ) in the 2015 and 2016 field seasons. The crop was drilled in mid-March in both seasons. Spore traps operated with a 2-mm air inlet, powered from $12 \mathrm{~V}$ batteries recharged by a solar panel and collected spores between mid-June and midSeptember. The air flow was set to 10 liters/min $\left(14 \mathrm{~m}^{3} /\right.$ day $)$. Adhesive used to collect air particles on transparent Melinex tape was as follows: $23 \%$ petroleum jelly (Vaseline), $14 \%$ paraffin wax, and $3 \%$ phenol, which was applied as a suspension in hexane (adapted from Lacey and West 2006). Tapes were replaced weekly, and exposed drums were sent to the Rothamsted Research Institute laboratory for testing. Tapes were cut into two equal replicate sections covering each 24-h sampling period and stored at $-20^{\circ} \mathrm{C}$ until processed. DNA was extracted from one of these replicate tape samples using a Master Pure Yeast DNA extraction kit (into a final volume of $100 \mu \mathrm{l}$ ). LAMP assay testing was done as previously described. Each run included standards of known amounts of $U$. betae DNA (10 ng, $1 \mathrm{ng}, 100 \mathrm{pg}, 10 \mathrm{pg}$, and $1 \mathrm{pg}$ ), and the equation from the resulting standard curve was used to estimate amounts of pathogen DNA in each sample. Additionally, to test the possibility of inhibition in environmental samples, selected negative samples were spiked with $1 \mathrm{ng}$ of pure $U$. betae DNA.

\section{Results}

LAMP assay validation. The new LAMP assay targeted to $U$. betae cytochrome $b$ DNA sequence amplified specifically this target species and could detect pathogen strains from main sugar beet growing regions from across England and two sites in Denmark. These positive samples all yielded a single dissociation curve of 84 to $85^{\circ} \mathrm{C}$ (Fig. 1). By contrast, the assay did not detect several closely related fungi, nor a broad range of other commonly occurring sugar beet pathogens (Table 2). Sensitivity screening indicated the $U$. betae LAMP assay could consistently detect down to $10 \mathrm{pg}$ of pure pathogen DNA (Fig. $1 \mathrm{~A}$ and $\mathrm{B})$; although a signal was also sometimes given with as little

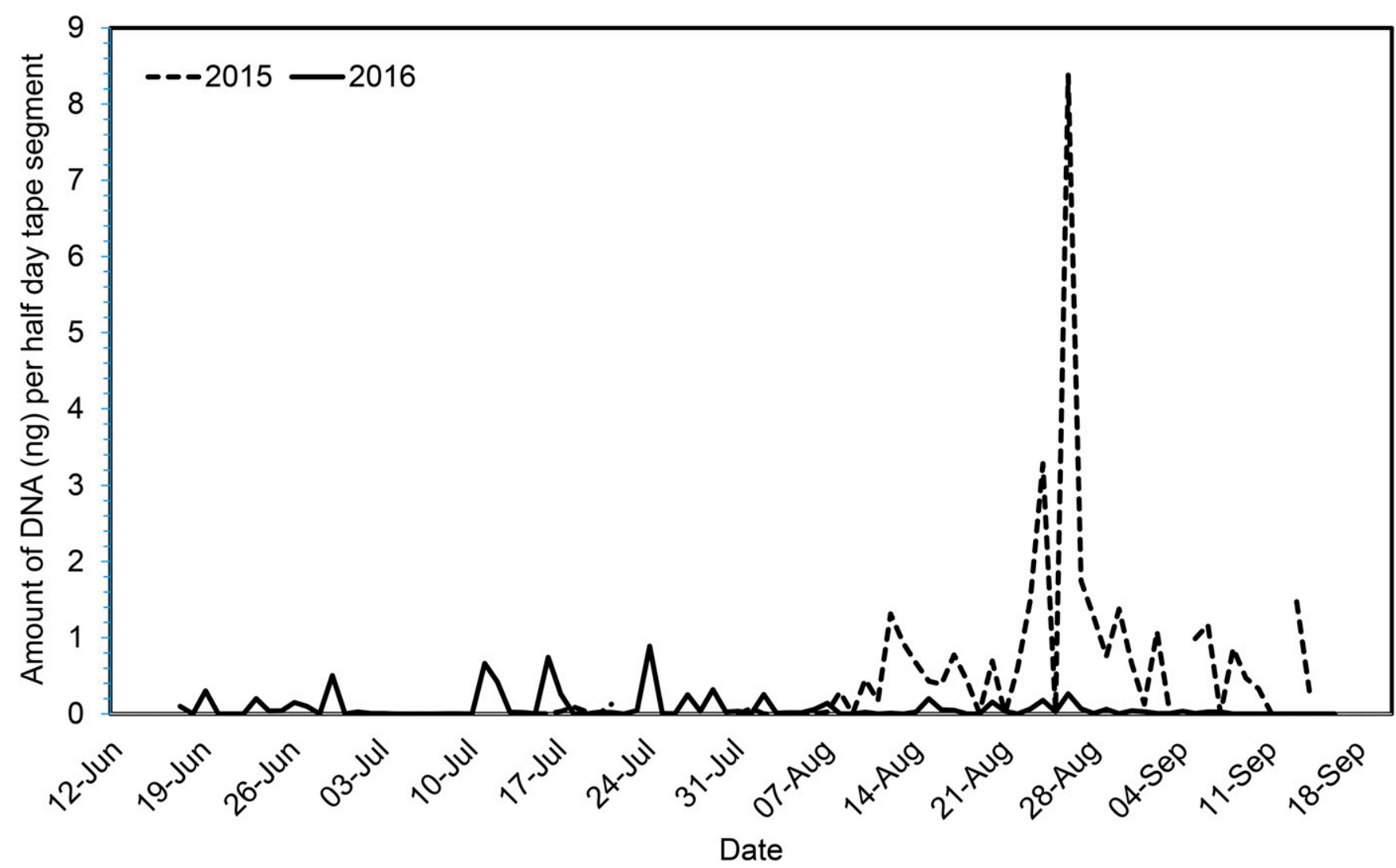

Fig. 2. Use of the new Uromyces betae LAMP assay to estimate the amount of DNA per day in air samples collected from a single sugar beet field site in alternate 2015 and 2016 seasons. 
as $1 \mathrm{pg}$ of DNA, this result was obtained only approximately $50 \%$ of the time and was hence not consistently repeatable (data not shown).

When $\mathrm{Ct}$ values obtained from testing varying amounts of pure $U$. betae genomic DNA were plotted against those from known numbers of spores (from which DNA had been extracted), a positive linear correlation was observed.

LAMP assay applied to air spore tape samples. The LAMP assay was successfully applied to air spore tape samples collected over two alternate growing seasons (2015 and 2016) by the spore trap placed near the untreated plots at the fungicide trial in Suffolk. Differences in the amounts of airborne pathogen inoculum were observed between both years. As indicated in 2015, the first arrival of $U$. betae spores was detected later in the season (early July) than in 2016 (mid-June) (Fig. 2). Overall, 2015 was a year with higher presence of inoculum in the air, with the peak on a day in mid-August. In contrast, during sampling in 2016, the amount of pathogen's DNA detected from early August until the end of sampling in mid-September remained sporadic and low.

\section{Discussion}

This study describes the first molecular diagnostic, based on cytochrome $b$ DNA sequences, for rapid, specific, and direct detection of $U$. betae, the cause of sugar beet rust and a major threat to sugar beet crops in the United Kingdom. Prior to this, identification of $U$. betae was based on microscopic and morphological analyses or required
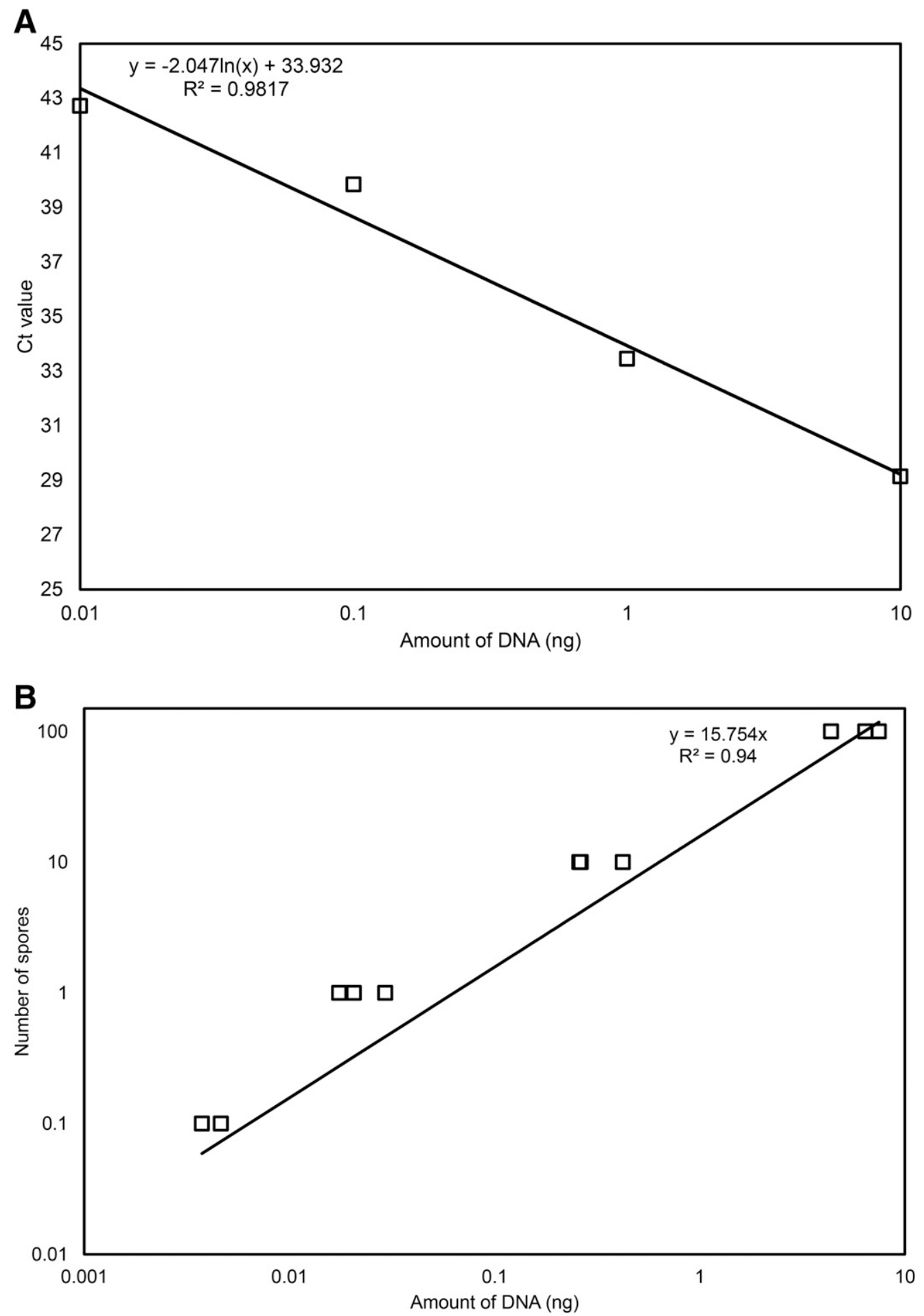

Fig. 3. Screening of the new Uromyces betae LAMP assay against serially diluted amounts of pathogen DNA (A) or known dilutions of spores (B). Results are shown on the log scale. $\mathrm{Ct}=$ crossing threshold. Representative results shown are the mean of three technical replicates. 
further sequencing (Mahlein et al. 2010, 2012). The developed LAMP assay detected only $U$. betae strains and not those from other closely related Uromyces or Puccinia species, nor other commonly occurring sugar beet pathogens (e.g., C. beticola, E. betae, and $R$. beticola). Although LAMP assays have previously been described for several economically important phytopathogens, for example, Botrytis cinerea (gray mold) and Guignardia citricarpa (citrus black spot) (Duan et al. 2014; Tomlinson et al. 2013b), this study describes the first such assay for a sugar beet pathogen.

Use of the LAMP assay enabled fast detection of the pathogen within $<30 \mathrm{~min}$, and more often $<20 \mathrm{~min}$. Sensitivity testing revealed a robust signal down to $10 \mathrm{pg}$ of $U$. betae pathogen DNA, with sporadic detection down to $1 \mathrm{pg}$, which was therefore excluded from subsequent analyses. A clear linear relationship $\left(R^{2}=0.9817\right)$ (Fig. $3 \mathrm{~A})$ was observed in screening of known amounts of pathogen DNA (10 ng, $1 \mathrm{ng}, 100 \mathrm{pg}$, and $10 \mathrm{pg}$ ) and $\mathrm{Ct}$ (crossing threshold) value. A similar result was found in testing against DNA extracted from known numbers of $U$. betae spores that had been deposited onto pieces of waxed Melinex tape, with a positive linear correlation $\left(R^{2}=\right.$ 0.94) (Fig. 3B). In previous studies, DNA extracted directly from Melinex tape samples has been used to quantify amounts of DNA of fungal pathogens in air samples, and it was showed to be efficient enough despite possible presence (and consequently qPCR/LAMP inhibition) of dust or other microorganisms (Rittenour et al. 2012; Wieczorek et al. 2014).

However, it should be noted that similar $\mathrm{Ct}$ values were obtained from DNA extracted from $\leq 1$ spore, indicating that below this threshold very small amounts of pathogen DNA cannot be reliably quantified using the assay. Furthermore, it is possible that gene copy number may vary between different $U$. betae strains, and thus the results might therefore be best considered semiquantitative (i.e., high versus low) at the present time. Nevertheless, similar $\mathrm{Ct}$ values were obtained using the new LAMP assay from DNA extracted from known amounts of spores from three different $U$. betae field strains, and thus this does not appear to be the case (data not shown).

Testing of the new LAMP assay against DNA extracted from a known number of $U$. betae spores revealed a positive linear correlation $\left(R^{2}=0.94\right)$, indicating that the assay could be used to estimate amounts of pathogen inoculum in environmental samples by using the established model. Subsequently, the assay was successfully applied to air spore tape samples collected from a single sugar beet site in Suffolk over two consecutive growing seasons. Pathogen inoculum levels, as determined by LAMP, increased markedly, with numerous spike periods between mid-August and midSeptember in the 2015 season but not the 2016 season. Interestingly, field disease severity data (percentage of leaf cover with visible sugar beet rust symptoms) from both years in August/ September were low $(\leq 3 \%)$, but they were considerably higher in October 2015 (25\%) than October 2016 (2\%) (Mark Stevens, BBRO, unpublished data). These observations suggest that early detection of airborne $U$. betae inoculum, as opposed to simply visual inspection of sugar beet crops alone when the pathogen may be growing asymptomatically, might (subject to more extensive testing and validation) allow potential disease severity later in the growing season to be predicted.

LAMP offers several potential advantages over conventional PCR that could allow field-based use. These include the requirement of only a single reaction temperature that can be combined with lyophilized reagents. Moreover, given the speed of LAMP $(<30 \mathrm{~min})$, this opens up the prospect of real-time monitoring of pathogen inoculum. The LAMP assay described here for $U$. betae could be used as a component of a sugar beet rust disease forecasting system that incorporates data on pathogen inoculum present in air samples. Such information could be combined in models with additional agronomic (e.g., cultivar resistance ratings and fungicide usage) and weather (e.g., temperature and humidity) data that are likely to influence progression of the disease (Draycott 2008; https://bbro.co.uk/). This could form the basis of a future disease forecasting system, guiding end users to ensure more precise and integrated strategies for better control of sugar beet rust.

\section{Acknowledgments}

The technical assistance of our colleagues at the University of Nottingham and Rothamsted Research is acknowledged. We also thank colleagues at BBRO for allowing access to field trials and provision of leaf samples and Thies Marten Heick from Aarhus University for providing us DNA from Danish isolates of $U$. betae.

\section{Literature Cited}

Aoi, Y., Hosogai, M., and Tsuneda, S. 2006. Real-time quantitative LAMP (loopmediated isothermal amplification of DNA) as a simple method for monitoring ammonia-oxidizing bacteria. J. Biotechnol. 125:484-491.

Bekele, B., Hodgetts, J., Tomlinson, J., Boonham, N., Nikolić, P., Swarbrick, P., and Dickinson, M. 2011. Use of a real-time LAMP isothermal assay for detecting 16SrII and XII phytoplasmas in fruit and weeds of the Ethiopian Rift Valley. Plant Pathol. 60:345-355.

Biswas, S. K., Yokoyama, K., Nishimura, K., and Miyaji, M. 2001. Molecular phylogenetics of the genus Rhodotorula and related basidiomycetous yeast inferred from the mitochondrial cytochrome $b$ gene. J. Syst. Evol. Microbiol. 51:1191-1199.

Draycott, A. P. 2008. Sugar Beet. Wiley, Hoboken, NJ.

Duan, Y. B., Ge, C. Y., Zhang, X. K., Wang, J. X., and Zhou, M. G. 2014 Development and evaluation of a novel and rapid detection assay for Botrytis cinerea based on loop mediated isothermal amplification. PLoS One 9:e111094.

Grasso, V., Palermo, S., Sierotzki, H., Garibaldi, A., and Gisi, U. 2006 Cytochrome $b$ gene structure and consequences for resistance to Qo inhibitor fungicides in plant pathogens. Pest Manag. Sci. 62:465-472.

Kogovšek, P., Hodgetts, J., Hall, J., Prezelj, N., Nikolić, P., Mehle, N., Lenarčič R., Rotter, A., Dickinson, M., Boonham, N., Dermastia, M., and Ravnikar, M. 2015. LAMP assay and rapid sample preparation method for on-site detection of flavescence dorée phytoplasma in grapevine. Plant Pathol. 64:286-296.

Lacey, M. E., and West, J. S. 2006. The Air Spora. Springer, Dordrecht, The Netherlands.

Mahlein, A. K., Steiner, U., Dehne, H. W., and Oerke, E.-C. 2010. Spectral signatures of sugar beet leaves for the detection and differentiation of diseases. Precis. Agric. 11:413-431.

Mahlein, A.-K., Steiner, U., Hillnhütter, C., Dehne, H.-W., and Oerke, E.-C. 2012. Hyperspectral imaging for small-scale analysis of symptoms caused by different sugar beet diseases. Plant Methods 8:3.

Nagamine, K., Hase, T., and Notomi, T. 2002. Accelerated reaction by loop-mediated isothermal amplification using loop primers. Mol. Cell. Probes 16:223-229.

Newton, M., and Peturson, B. 1943. Uromyces betae in Canada. Phytopathology $33: 10$

Notomi, T., Okayama, H., Masubuchi, H., Yonekawa, T., Watanabe, K., Amino, N., and Hase, T. 2000. Loop-mediated isothermal amplification of DNA. Nucleic Acids Res. 28:e63

OEPP/EPPO. 1994. EPPO Standard PP 2/1(1). Guideline on good plant protection practice: Principles of good plant protection practice. EPPO Bull. 24:233-240.

O'Sullivan, E. 1997. Responses of sugar-beet cultivars to the control of rust (Uromyces betae). Irish J. Agric. Food Res. 36:175-184

Rittenour, W. R., Park, J.-H., Cox-Ganser, J. M., Beezhold, D. H., and Green, B. J. 2012. Comparison of DNA extraction methodologies used for assessing fungal diversity via ITS sequencing. J. Environ. Monit. 14:766-774.

Soerensen, F., and Marcussen, C. 1996. Rust Uromyces betae in Denmark, inoculum sources and effect on sugar beet yield. Comptes-Rendus des Congres de l'Institut International de Recherches Betteravieres, Belgium

Tomlinson, J. A., Dickinson, M. J., and Boonham, N. 2010. Detection of Botrytis cinerea by loop-mediated isothermal amplification. Lett. Appl. Microbiol. 51: 650-657.

Tomlinson, J. A., Ostoja-Starzewska, S., Adams, I. P., Miano, D. W., Abidrabo, P., Kinyua, Z., Alicai, T., Dickinson, M. J., Peters, D., Boonham, N., and Smith, J. 2013a. Loop-mediated isothermal amplification for rapid detection of the causal agents of cassava brown streak disease. J. Virol. Methods 191:148-154.

Tomlinson, J. A., Ostoja-Starzewska, S., Webb, K., Cole, J., Barnes, A., Dickinson, M., and Boonham, N. 2013b. A loop-mediated isothermal amplification-based method for confirmation of Guignardia citricarpa in citrus black spot lesions. Eur. J. Plant Pathol. 136:217-224.

van der Merwe, M., Ericson, L., Walker, J., Thrall, P. H., and Burdon, J. J. 2007. Evolutionary relationships among species of Puccinia and Uromyces (Pucciniaceae Uredinales) inferred from partial protein coding gene phylogenies. Fungal Biol. 111:163-175.

Wang, L., Yokoyama, K., Miyaji, M., and Nishimura, K. 1998. The identification and phylogenetic relationship of pathogenic species of Aspergillus based on the mitochondrial cytochrome $b$ gene. Med. Mycol. 36:153-164.

Wieczorek, T. M., Jørgensen, L. N., Hansen, A. L., Munk, L., and Justesen, A. F 2014. Early detection of sugar beet pathogen Ramularia beticola in leaf and air samples using qPCR. Eur. J. Plant Pathol. 138:775-785.

Williams, R. H., Ward, E., and McCartney, H. A. 2001. Methods for integrated air sampling and DNA analysis for detection of airborne fungal spores. Appl. Environ. Microbiol. 67:2453-2459.

Ye, J., Coulouris, G., Zaretskaya, I., Cutcutache, I., Rozen, S., and Madden, T. 2012. Primer-BLAST: A tool to design target-specific primers for polymerase chain reaction. BMC Bioinformatics 13:134. 